\section{CYRIL G. HOPKINS}

Dr. Cyril G. Hopkins, head of the department of agronomy of the University of Illinois, passed away at the British Military Hospital at Gibraltar, on October 6, of congestion of the brain with malarial complications.

$\mathrm{He}$ had finished a year's work in the study of the exhausted soils of Greece under the auspices of the American Red Cross, had made his official report, had seen to the preparation of a Greek translation, had been decorated by the King of Greece "for distinguished service," and had taken ship for home when, without warning, the third day out from Gibraltar, the fatal illness struck him and at the age of fifty-three at the very zenith of his powers, his service was brought to an end. Just what that service was, I shall attempt to state as clearly as it is possible for a layman to state it.

Dr. Hopkins was a chemist both by training and by instinct. He had the chemist's conception that everything about us is built up of well-known elements in varying but definite proportions. He carried this conception into crops and into the study of soils which provides certain of the necessary elements in crop production. He was keenly impressed with the fact that most crops are produced out of the natural store of plant food just as coal is produced from the mines without restoration, and that this being the case, the individual can not compete against an agriculture which mostly draws upon virgin stores if he undertakes to apply to his land anything more than what is necessary to increase the amount "of the limiting element." By this, he meant the particular form of plant food which chances to be lacking and, therefore, which limited the combinations which might be made in the form of plants. $\mathrm{He}$ announced the doctrine that the farmer should first know his soil by an inventory of its constituents, particularly those likely to run short as a merchant takes frequent inventory of his stock and places timely orders where the stock is running short, leaving the full shelves alone until they shall begin to run low.

With this view of the situation, he made scientific objections to the whole theory of prepared mixed fertilizers just as he did to the idea of a patent medicine, believing with the physician that the first step is to diagnose the situation and then to find the particular remedy that is needed and apply it. He particularly objected to the use of "acid phosphates" partly because of cost arising from the fact that a full half of the weight consisted of sulphuric acid which is not a fertilizer and partly because of the fact that the acidity of soils, even under normal conditions needs frequent correction in order that the bacteria may thrive upon the roots of legumes and the store of nitrogen be properly increased.

Again with this conception of maintaining fertility, Dr. Hopkins believed, and his experiments seemed to confirm the belief, that sufficient amounts. of nitrogen for ordinary farming purposes could be obtained by proper rotation of crops introducing the legumes with reasonable frequency, provided that soils were not allowed to become acid and that suitable measures were taken to promote bacterial growth.

The great slogan which Dr. Hopkins constantly employed was that of a "Permanent Agriculture," by which he meant that in the application of fertility, regard should be had, not only for the immediate results, but for the permanent effect thon the land, the test of which lay in this question: "Am I applying in my fertilizers as much phosphorus or potassium as $I$ am removing in my crops and am $I$ abstracting from the atmosphere by my rotations enough nitrogen to restore the draft upon the land?" $\mathrm{He}$ insisted that every farmer should not only be able to answer this question in the affirmative, but that if he chose for application the cheapest sources of plant food, he would be able to apply a little more year by year than he took out.

For this reason, the system which Dr. Hopkins advocated was the application of enough fertilizer to replace what would be taken out by a hundred bushels of corn, fifty bushels of wheat and so on for the other maximum yields. In this way, he argued-and seemed fully able to prove-that the American farmer 
could build up an agriculture that would be not only profitable but also permanent and increasingly productive.

\section{E. Davenport}

\section{SCIENTIFIC EVENTS}

\section{ATOMIC ENERGY}

AT the second day of the James Watt centenary commemoration at Birmingham those present heard an address by Sir Oliver Lodge foreshadowing the possible employment of atomic energy.

According to the report in the London Times Sir Oliver Lodge said that, in view of the fact that the sources of molecular energy are beginning to show signs of exhaustion, he ventured to assume that if James Watt were living to-day he would be directing his attention to discovering whether there are other stores of energy at present almost unsuspected. The fact was that contained in the properties of matter there was an immense source of energy so far inaccessible, but which he saw no reason why the progress of discovery should not make available. He referred to atomic energy which, if it could be utilized on an extensive scale, would, he believed, greatly ameliorate the conditions of factory life. There would be no smoke due to imperfect combustion and no dirt due to the transit of coal or ashes, while the power would be very compact and clean. Possibly there might occasionally be explosions due to the liberation of power more quickly than it was wanted, but in general he presumed that the conditions of utilization would be good.

Sir Oliver explained that the secret of this power began to be given away when radio-activity was discovered, and said that at present we were hardly at the beginning of its utilization. The discovery of radium, which soon followed, excited universal interest and aroused great surprise, because radium appeared to give off energy continually without being consumed. The truth was that it did disappear as it gave off its energy, but the disappearance was so slow and the energy given off so remarkable that it was not surprising that one was noticed before the other.
The energy of radium, however, was not under control, and it went on emitting energy at its own proper rate without regard to accidental circumstances. What happened was that every now and then a particle was projected. The energy stored in an atom was something enormous, and if we could make the atoms fly off when we wanted there would be available a source of energy which would put everything else into the background. This energy was contained in all forms of mater and was not confined to radio-active substances. If a stimulus could be found the utilization of this source of energy would be possible. We appeared to be on the verge of utilizing a minute fraction of it, and it was this energy which had made wireless telephony possible.

\section{STATISTICS OF THE NATURAL GAS INDUSTRY}

A REPORT on "Natural Gas and Natural Gasoline in 1917 " by John D. Northrop, just published by the Geological Survey, gives statistics of the production and consumption of natural gas and sketches the condition of the industry in 25 states. It gives also statistics concerning gasoline made from natural gas in that year.

More than 2,100 cities and towns in the United States are supplied with natural gas, which is furnished to domestic consumers at rates that should arouse the envy of those consumers of artificial gas who have to pay about a dollar a thousand cubic feet. The average price per thousand cubic feet charged to consumers of natural gas in the United States in 1917 was about 30 cents. The average price charged to manufacturers was less than 12 cents.

Most of the towns and cities supplied with natural gas are in New York Pennsylvania, Ohio, West Virginia, Kansas, Oklahoma and California. In Ohio 872,000 domestic consumers were supplied in 1917, In Pennsylvania 480,000 , in California 239,000 , in. Kansas 188,000, in New York 164,000, in West Virginia 129,000, and in Oklahoma 95,000 . The industrial consumers, by whom the gas is used for manufactures or for generating power, use twice as much gas as the domestic users. 